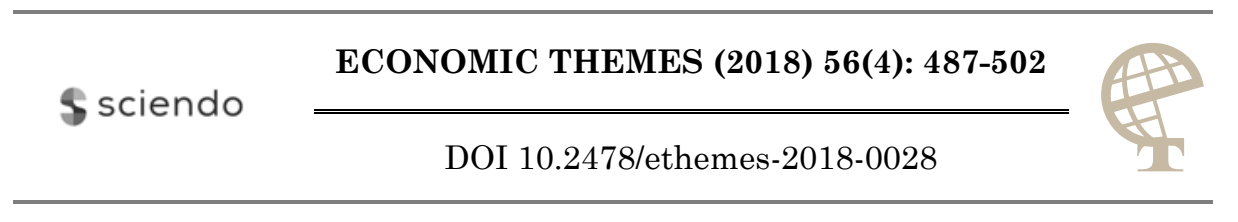

\title{
DEVELOPMENT PERFORMANCE OF THE TEXTILE INDUSTRY OF SERBIA
}

\author{
Vladimir Kostić \\ Faculty of Economics in Kosovska Mitrovica, University of Pristina \\ $\triangle$ vladakostic1985@gmail.com
}

Miloš Milutinović

IQ centar, Belgrade, Serbia

$\bowtie$ milos.milutinovic@bdsconsulting.rs

\section{Miroljub Nikolić}

Ministry of Economy, Department of Investments, Belgrade, Serbia

\author{
$\triangle$ miroljubnk@gmail.com
}

$\mathrm{UDC}$

$667.2(497.11)$

Review paper

Received: 14.9.2018

Accepted:

28.12.2018

\begin{abstract}
The textile industry is still significantly involved in production and employment in developed countries and is a major source of growth in many developing countries. As a business with a long history, the textile industry undergoes radical transformations at a global level. With the emergence of new competitors, global business conditions have changed significantly. Nevertheless, European manufacturers have remained world leaders in the production of industrial textiles and fashion clothing. Many European manufacturers resort to subcontracting or relocating capacity for labour-intensive activities in countries with lower labour costs, such as Serbia, in order to maintain competitiveness. The greatest success of the domestic textile industry was recorded in the late 1980s when it was a significant source of employment, the creation of added value and more balanced regional development. Although it is still not at the level of the 1980s, positive developments in the domestic textile industry appeared in 2016 in the direction of growth in production, employment and exports. The state seeks to accelerate the development of the textile industry through the subsidisation of foreign and domestic investors. However, growth that is primarily based on foreign direct investment is a long-term unsustainable concept. In order for growth to be sustainable, it is necessary to encourage the development of activities that produce greater added value and increase competitiveness. That is the reason why it is necessary to support the development of domestic enterprises, as well as the arrival of those foreign investments that generate multiple levels of added value.
\end{abstract}


Keywords: textile industry, business performance, domestic and foreign direct investments, development

JEL classification: L16, L67, N10, O14, P45

\section{Basic movements in the frame of the textile industry}

The textile industry includes the production of textiles and textile products, namely natural fibers (cotton, wool, silk, flax, hemp and jute) and artificial fibers including those which result from the transformation of natural polymers (viscose, acetate and modal), synthetic fibers (organic fibers based on petrochemicals such as polyester, nylon/polyamide, acrylic and polypropylene) and fibers from inorganic materials (carbon or ceramics), as well as the transformation of natural and artificial fibers into fabrics and final products such as technical or industrial textiles, carpets and other floor covering textile, home textiles (curtains, tablecloths, bedspreads, bed sheets, towels, ropes, etc.), clothing in the form of work clothes (uniforms, work suits, aprons, etc.), everyday and fashion clothing, underwear, socks ect. It is a production activity with a long history that is still a generator of production growth in many developing countries and it makes up $6 \%$ of production and $14 \%$ of employment in the field of the manufacturing industry in the world.

Although the production of textiles characterised by raw material orientation, technological intensity and organisational concentration of production in higher standardised quantities differs from the production of textile products, which is more intensive and fragmented, and more directed to the final consumer, it is still a technologically and commercially integrated unit so that the production of textiles and textile products can be observed together in the field of the textile industry.

Over the past several decades, the textile industry has undergone radical transformations, due to technological changes, the evolution of production costs, the appearance of significant international competitors, and the elimination of import quotas since 2004 (Kathuria, et al., 2001). These factors greatly accelerated the flows of globalization characterised by large migrations of production and employment from developed to less developed countries (for example, from Germany to Poland, from Hong Kong to China, from Italy to Turkey and Hungary and later to Romania and Bulgaria), so that the textile industry has become one of the most globalised industries in the world.

More than four million jobs have already been shut down in developed countries since producers reacted to competitive pressure by relocating production to countries with faster demand for textile products, modernising equipment and accepting new working methods that involve the transfer of sewing activities to low-income countries (OECD, 2004). However, suppliers in small developing countries and least developed countries which are specialised in the final sewing of imported textiles are also sensitive to competitive pressure and global demand changes (Irun, 2017). 


\section{Economic importance of the textile industry in the European Union}

European manufacturers have remained world leaders in the markets for technical/industrial textile and non-woven materials (industrial filters, hygiene products, automotive and medical products, etc.) as well as high-quality fashionable clothing with high design content. To maintain competitiveness, many European manufacturers resort to subcontracting or relocating their production capacities for labour-intensive activities, such as sewing clothes, in countries with lower labour costs.

Despite all the global challenges, the textile industry has remained an important part of the European economy (accounting for 3\% of GVA and 6\% of total EU production) and it contributes significantly to social well-being in many parts of Europe (over 70\% are women). Only in 2016, 174 thousand enterprises were in the textile industry within the European Union (1.8\% more compared to 2015), which employed 1.7 million workers ( $+0.3 \%$ compared to 2015 ), realised a turnover of $€ 169$ billion $(+2.3 \%)$, created a GVA of $€ 45$ billion $(+2.5 \%)$ and recorded exports of $€ 45$ billion ( $+3.6 \%$ ) (EURACTIVE, 2018).

The largest manufacturers within the European textile industry are: Italy, France, Great Britain, Germany and Spain, which together make three quarters of production in the EU. Countries like Italy, Greece and Portugal, and some of the newer EU member states, such as Romania, Bulgaria and Poland, and to a lesser extent Spain and France, contribute more to the overall production of clothing. On the other hand, countries such as Great Britain, Germany, Belgium, the Netherlands, Austria and Sweden contribute more to the production of textiles, primarily in the field of technical textiles. The basic characteristic of the textile industry in the EU is that it is based on small enterprises, with companies which employ less than 50 workers and more than $90 \%$ of the workforce is employed producing almost $60 \%$ of value added. About $20 \%$ of EU production is sold outside the EU, despite the access to many markets in the world which is still limited.

\section{Development of the textile industry in Serbia}

The development of the textile industry in Serbia has a long and, in some periods, successful history. The greatest success of the domestic textile industry was recorded at the end of 1980s when it was the most important source of employment besides the food and machinery industry (this especially included the employment of women), the creation of added value and more balanced regional development. A good example is 1989 when the textile industry accounted for $6.0 \%$ of the total social product and employed about 7\% of employees (about 170,000 workers, out of which 125,000 women) in the economy (group of authors, 2003). 
The textile industry was well positioned in foreign markets managing to compete with quality, and the export of the textile sector accounted for $9 \%$ of the total export of the economy. However, the unfavourable business environment of the 1990s had a negative impact on the functioning and development of the textile industry due to the loss of the market (sanctions and the reduction of the domestic market because of the decline in living standards), macroeconomic instability, various restrictions, the inability of normal financing, as well as the inability and incompetence to be involved in global flows and structural transformations on a global level.

In addition to this, although the textile industry does not have the importance it had three or more decades ago, it remains an important part of the domestic economy. In 2016, 6.898 enterprises (accounting for $12.9 \%$ of the enterprises in the manufacturing industry, or $2.0 \%$ of the nonfinancial part of the economy), which operate within the textile industry, employ 44.859 workers $(11.7 \%$ and $3.5 \%$ respectively), generate $€ 1,1$ billion of turnover (4.4\%, or $1.3 \%)$, make $€ 335$ mil. of GDP $(6.4 \%$, or $1.9 \%)$, records $€ 796$ mil. of export ( $8.1 \%$ and $6.0 \%$ respectively) and generate surplus in foreign exchange of $€ 229$ million $(14.6 \%)$.

Chart 1. The share of the textile industry in the basic indicators of the business in Manufacturing industry and the non-financial part of the Serbian economy in 2016.

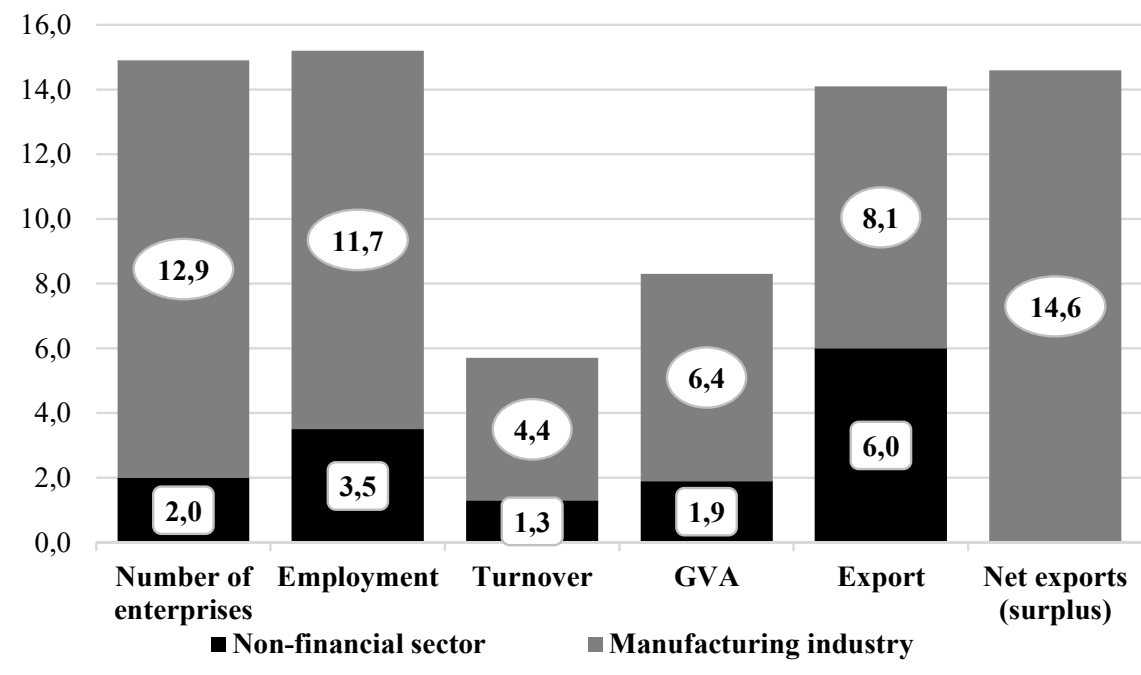

Source: authors, based on the Republic Statistical Office data

\subsection{Number of enterprises in the textile industry in Serbia}

In $2016,6.898$ companies operated in the textile industry (5.501 entrepreneurs, 1.369 micro, small and medium enterprises and 28 large companies). In the 
production of textiles 1.714 enterprises were engaged (25\% of all textile industry enterprises), while in the production of textile products 5.183 enterprises were engaged (75\%).

Table 1. Number of enterprises in the textile industry in the period 2010-2016.

\begin{tabular}{|r|r|r|r|r||}
\hline \hline & $\begin{array}{l}\text { Manufacture } \\
\text { of textile }\end{array}$ & $\begin{array}{c}\text { Manufacture } \\
\text { of textile products }\end{array}$ & $\begin{array}{l}\text { Textile } \\
\text { industry }\end{array}$ & $\begin{array}{c}\text { Annual } \\
\text { growth in \% }\end{array}$ \\
\hline 2010 & 1,845 & 5,183 & $\mathbf{7 , 0 2 7}$ & 1.6 \\
\hline 2011 & 1,562 & 5,185 & $\mathbf{6 , 7 4 8}$ & -4.0 \\
\hline 2012 & 1,764 & 4,855 & $\mathbf{6 , 6 1 9}$ & -1.9 \\
\hline 2013 & 1,673 & 4,771 & $\mathbf{6 , 4 4 4}$ & -2.6 \\
\hline 2014 & 1,699 & 4,880 & $\mathbf{6 , 5 8 0}$ & 2.1 \\
\hline 2015 & 1,661 & 4,941 & $\mathbf{6 , 6 0 2}$ & 0.3 \\
\hline 2016 & 1,714 & 5,183 & $\mathbf{6 , 8 9 8}$ & 4.5 \\
\hline Compound Annual Growth Rate (CAGR) $2010-2016$ & & 0,0 \\
\hline
\end{tabular}

Source: authors, based on the data of the Republic Statistical Office

Chart 2. Movement of the number of companies in the textile industry in the period 2010-2016.

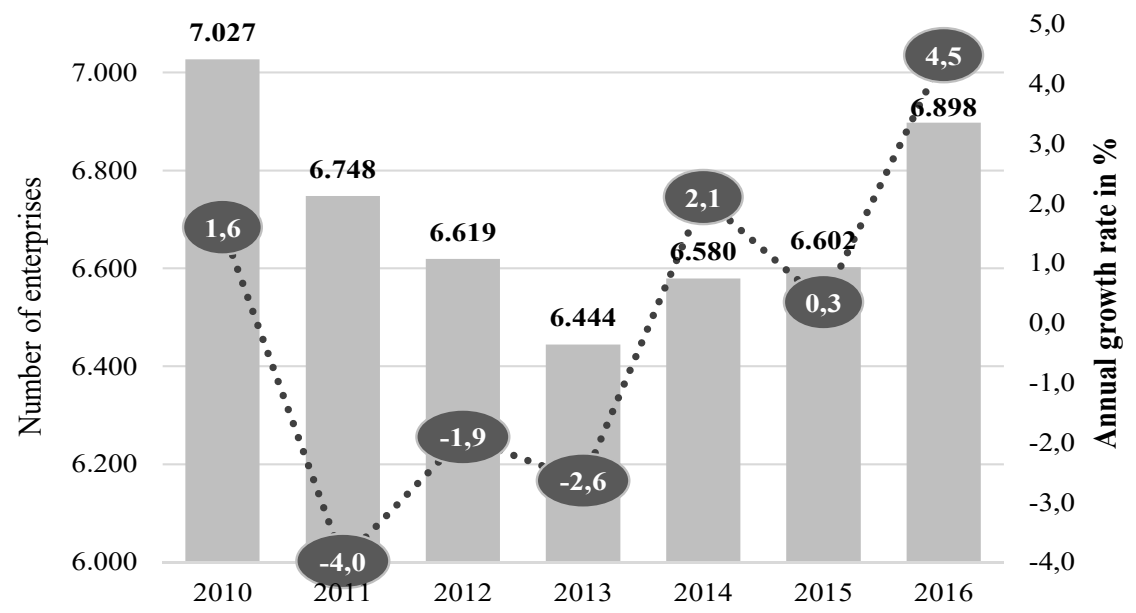

Source: authors, based on the Republic Statistical Office data

In the period 2010-2016, the largest number of enterprises in the textile industry was registered in 2010 (7,027 enterprises), and in the next three years this number decreased, so that in 2014 only 6.444 enterprises operated in the textile industry. The situation changed in 2015, and especially in 2016, when the number 
of enterprises was reestablished (in 2016 compared to 2015 the number of enterprises increased by 295 , or by $4.5 \%$ ). However, despite the growth, the number of companies operating in the textile industry in 2016 is lower for 130 companies than in 2010 .

\subsection{Employment in the textile industry of Serbia}

Textile industry employed 44.859 workers in 2016, with 11.244 workers in the textile production ( $25 \%$ of all employees in the textile industry), and 33.615 workers $(75 \%)$ were engaged in the production of textile products.

Table 2. Employment in the textile industry in the period 2010-2016

\begin{tabular}{||l|r|r|r|r||}
\hline Year & $\begin{array}{c}\text { Manufacture of } \\
\text { textile }\end{array}$ & $\begin{array}{c}\text { Manufacture of textile } \\
\text { products }\end{array}$ & \multicolumn{1}{c|}{$\begin{array}{c}\text { Textile } \\
\text { industry }\end{array}$} & $\begin{array}{c}\text { Annual growth } \\
\text { in \% }\end{array}$ \\
\hline 2010 & 9,245 & 25,769 & $\mathbf{3 5 , 0 1 3}$ & -11.3 \\
\hline 2011 & 8,625 & 28,000 & $\mathbf{3 6 , 6 2 5}$ & 4.6 \\
\hline 2012 & 8,680 & 28,642 & $\mathbf{3 7 , 3 2 3}$ & 4.9 \\
\hline 2013 & 9,268 & 29,557 & $\mathbf{3 8 , 8 2 5}$ & 5.0 \\
\hline 2014 & 10,525 & 30,453 & $\mathbf{4 0 , 9 7 8}$ & 3.2 \\
\hline 2015 & 10,824 & 31,467 & $\mathbf{4 2 , 2 9 1}$ & 6.1 \\
\hline 2016 & 11,244 & 33,615 & $\mathbf{4 4 , 8 5 9}$ & 2,1 \\
\hline \multicolumn{4}{|c|}{ Compound Annual Growth Rate (CAGR) 2010-2016 } \\
\hline
\end{tabular}

Source: authors, based on the Republic Statistical Office's data

Chart 3. Employment trends in the textile industry in the period 2010-2016.

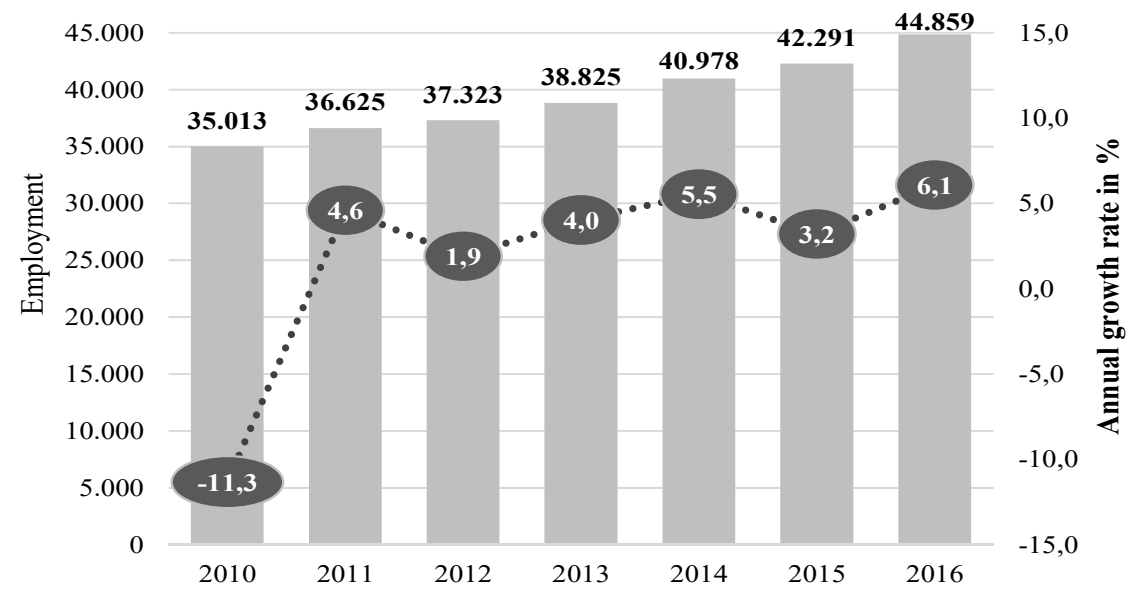

Source: authors, based on the Republic Statistical Office's data 
The highest employment, in the period 2010-2016 in the textile industry, was realised in 2016 ( 44.859 workers), which is 9.846 workers more than in 2010, with employment in the textile industry in the observed period which grew by an average of $2.1 \%$ annually. The fastest employment growth in the observed period was registered in 2016 (annual growth of employment of 6.1\%) and in 2014 $(5.5 \%)$, and the decline was recorded only in 2010 (decrease of $11.3 \%$ in relation to employment from 2009).

\subsection{Turnover of the textile industry of Serbia}

In 2016 , the enterprises of the textile industry made turnover worth $€ 1.1$ billion. In the field of textile production, the turnover amounted to $€ 357$ million $(33.7 \%$ turnover of the textile industry), while in the production of textile products turnover amounted to $€ 704.4$ million $(66.3 \%)$.

Table 3. Turnover in the textile industry in the period 2010-2016.

\begin{tabular}{|r|r|r|r|r|}
\hline \multicolumn{1}{|c|}{ Year } & $\begin{array}{c}\text { Manufacture of } \\
\text { textile } \\
\text { (million euro) }\end{array}$ & $\begin{array}{c}\text { Manufacture of } \\
\text { textile products } \\
\text { (million euro) }\end{array}$ & $\begin{array}{c}\text { Textile } \\
\text { industry } \\
\text { (million euro) }\end{array}$ & $\begin{array}{c}\text { Annual } \\
\text { growth (\%) }\end{array}$ \\
\hline 2010 & 187,3 & 427,3 & $\mathbf{6 1 4 , 6}$ & 4.1 \\
\hline 2011 & 209,2 & 490,2 & $\mathbf{6 9 9 , 5}$ & 13.8 \\
\hline 2012 & 222,9 & 545,3 & $\mathbf{7 6 8 , 3}$ & 9.8 \\
\hline 2013 & 233,8 & 611,1 & $\mathbf{8 4 5 , 0}$ & 10.0 \\
\hline 2014 & 260,1 & 618,6 & $\mathbf{8 7 8 , 7}$ & 4.0 \\
\hline 2015 & 305,4 & 639,2 & $\mathbf{9 4 4 , 6}$ & 7.5 \\
\hline 2016 & 357,5 & 704,4 & $\mathbf{1 , 0 6 1 , 9}$ & 12.4 \\
\hline \multicolumn{5}{|c|}{ Compound Annual Growth Rate (CAGR) 2010-2016 } \\
\hline
\end{tabular}

Source: authors, based on the Republic Statistical Office data

In the period 2010-2016 the value of turnover was constantly increasing (average real annual growth was $10.3 \%$ ), so in 2016 the turnover amounted to $€ 1.1$ billion which is by $€ 447.3$ million higher than the turnover realised in 2010 . Observed by years, the highest growth in turnover was registered in 2011 (annual growth of 13.8\%) and 2016 (12.4\%), and double-digit annual growth was recorded in $2013(10.0 \%)$. 
Chart 4: Traffic trends in the textile industry in the period 2010-2016.

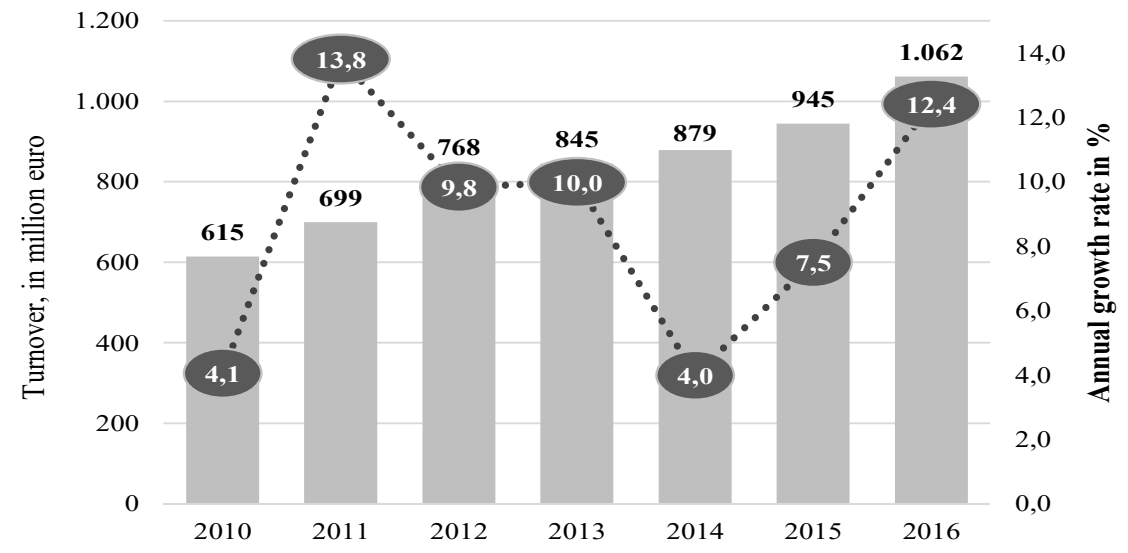

Source: authors, based on the Republic Statistical Office's data

\subsection{Gross added value created within the textile industry of Serbia}

Textile enterprises in 2016 created GVA in the amount of $€ 334.6$ million. The largest part of the GVA in the textile industry was created in the production of textile products ( $€ 226.7$ million - $67.8 \%$ of the GVA textile industry), while in the textile industry, GVA was realised in the amount of $€ 107.8$ million (32.2\%).

Table 4: Gross added value created in the textile industry in the period 2010-2016.

\begin{tabular}{|r|r|r|r|r|}
\hline \multicolumn{1}{|c|}{ Year } & $\begin{array}{c}\text { Manufacture of } \\
\text { textile } \\
\text { (million euro) }\end{array}$ & $\begin{array}{c}\text { Manufacture of } \\
\text { textile products } \\
\text { (million euro) }\end{array}$ & $\begin{array}{c}\text { Textile } \\
\text { industry } \\
\text { (million euro) }\end{array}$ & $\begin{array}{c}\text { Annual } \\
\text { growth (\%) }\end{array}$ \\
\hline 2010 & 51,8 & 149,5 & $\mathbf{2 0 1 , 3}$ & -1.2 \\
\hline 2011 & 52,0 & 155,0 & $\mathbf{2 0 7 , 1}$ & 2.9 \\
\hline 2012 & 59,3 & 161,8 & $\mathbf{2 2 1 , 1}$ & 6.8 \\
\hline 2013 & 65,0 & 171,2 & $\mathbf{2 3 6 , 2}$ & 6.8 \\
\hline 2014 & 73,0 & 188,6 & $\mathbf{2 6 1 , 6}$ & 10.8 \\
\hline 2015 & 90,4 & 204,3 & $\mathbf{2 9 4 , 7}$ & 13.6 \\
\hline 2016 & 107,8 & 226,7 & $\mathbf{3 3 4 , 6}$ & 8,6 \\
\hline
\end{tabular}

Source: authors, based on the Republic Statistical Office's data

The largest GVA in the textile industry was created in 2016 ( $€ 334.6$ million) and by $€ 133.3$ million is higher than the GVA created in 2010. After the decline in 2011 (decrease of 1.2\% compared to 2009), in the period 2011-2016, GVA grew steadily (at an average annual rate of $8.6 \%$ ), and the highest annual growth was recorded in 2015 (growth of 12.6\%) and in 2016 (13.5\%). 
Chart 5. Movement of GVA in the textile industry in the period 2010-2016.

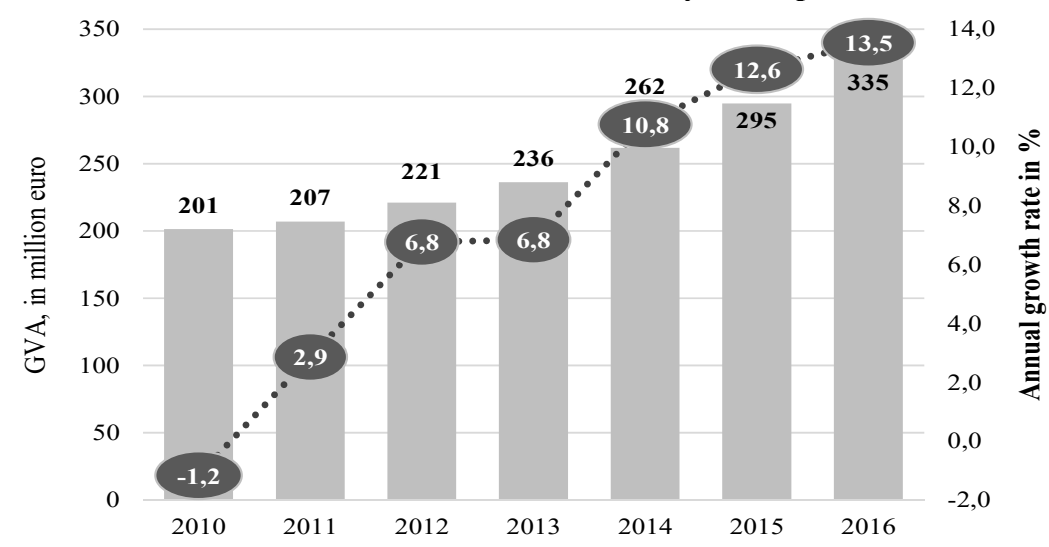

Source: authors, based on the Republic Statistical Office's data

\subsection{Export of the textile industry of Serbia}

In 2016, the textile industry of Serbia exported products worth $€ 796.1$ million which is for $€ 228.9$ more than imports, thus contributing positively to make the balance of trade with foreign countries.

Chart 6. Net export (surplus / deficit) of textile industry in Serbia in the period 2010-2016

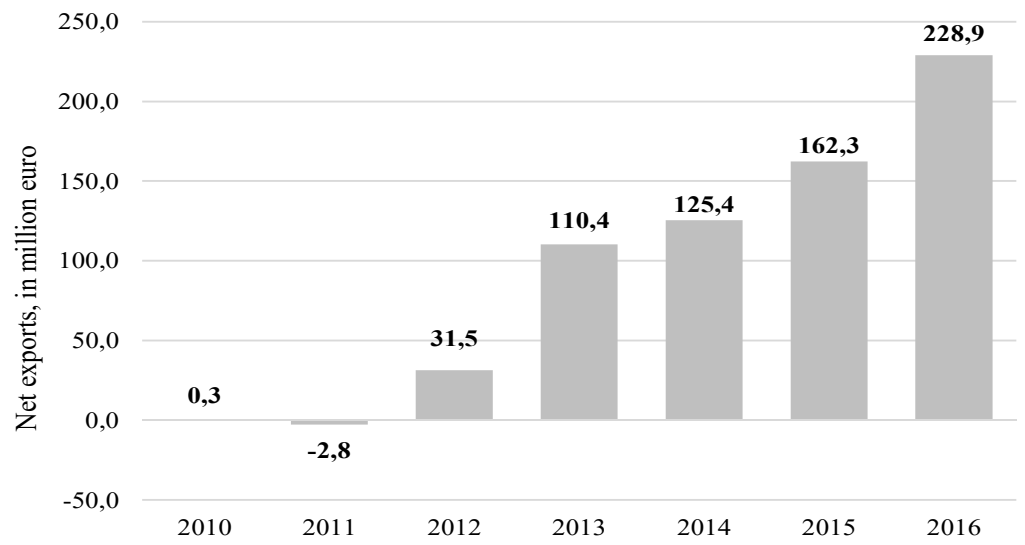

Source: authors, based on the Republic Statistical Office data

Domestic companies exported textiles in the amount of $€ 301.8$ million (37.9\% of export of textile industry) and realised a surplus in the trade exchange of 53.3 million euros. Domestic companies that exported textile products have achieved even better results because they created a foreign exchange inflow of $€ 494.3$ million (62.1\%), achieving a surplus worth 175.6 euros in trade with the world. 
Table 5. Export of textile industry in the period 2010-2016.

\begin{tabular}{|r|r|r|r|r||}
\hline \multicolumn{1}{|c|}{ Year } & $\begin{array}{c}\text { Manufacture of } \\
\text { textile } \\
\text { (million euro) }\end{array}$ & $\begin{array}{c}\text { Manufacture of } \\
\text { textile products } \\
\text { (million euro) }\end{array}$ & $\begin{array}{c}\text { Textile } \\
\text { industry } \\
\text { (million euro) }\end{array}$ & \multicolumn{1}{c|}{$\begin{array}{c}\text { Annual } \\
\text { growth (\%) }\end{array}$} \\
\hline 2010 & 50.7 & 254.4 & $\mathbf{3 0 5 . 1}$ & 4.5 \\
\hline 2011 & 69.7 & 290.1 & $\mathbf{3 5 9 . 8}$ & 17.9 \\
\hline 2012 & 79.4 & 354.2 & $\mathbf{4 3 3 . 6}$ & 20.5 \\
\hline 2013 & 124.2 & 414.3 & $\mathbf{5 3 8 . 5}$ & 24.2 \\
\hline 2014 & 185.9 & 428.4 & $\mathbf{6 1 4 . 4}$ & 14.1 \\
\hline 2015 & 250.8 & 420.6 & $\mathbf{6 7 1 . 4}$ & 9.3 \\
\hline 2016 & 301.8 & 494.3 & $\mathbf{7 9 6 . 1}$ & 18.6 \\
\hline \multicolumn{4}{|c|}{ Compound Annual Growth Rate (CAGR) 2010-2016 } & 18.2 \\
\hline
\end{tabular}

Source: authors, based on the Republic Statistical Office's data

In the period 2010-2016, exports grew at an average rate of 18.2\%. The highest export growth was recorded in 2012 (annual growth of 20.5\%) and in 2013 $(24.2 \%)$, and in 2016 , export growth was $18.6 \%$. The export value of $€ 491.0$ in 2016 is higher than in 2010, which indicates strengthening of the international competitiveness of the domestic textile industry and its return to the global market.

In the export of the domestic textile industry, clothing products occupy the greatest part (women's socks, underwear, sweaters, men's trousers), but also yarn, packaging bags, ropes, etc., but the main export markets are the EU countries and Russia. The largest exporters are foreign-owned enterprises (originated as Foreign Direct Investment - FDI and represent a move of production from developed European countries due to cheaper labour).

Enterprises that were created as FDI are mostly in the field of the textile production (Valy, Fiorano, Olimpias SRB, Gordon, Eurotay and others) and they mainly export socks, underwear, men's and women's clothes (sweaters, shirts and dresses), and companies which are producers of textile (Fulgar East, Confezioni Andrea Serbia, Flash Srb, Magna Seating, Pretty Sweaters, etc.) mainly focused on the production of yarns, fabrics and products for the automobile industry.

Export was also increased by originally domestic, mostly small and medium enterprises. The export of originally domestic enterprises, which arose as a reflection of the entrepreneurial spirit of domestic businessmen, is largely fragmented because the textile industry is a favourable environment for the development of entrepreneurship in the form of craft shops and small and mediumsized enterprises due to relatively low costs of starting a business, great opportunities for product differentiation, demand in domestic and foreign markets, 
the existence of knowledge and tradition in production, and the possibilities for opening new spin-off companies in cities where former state-owned enterprises existed.

Chart 7: Trends in exports of the textile industry in the period 2010-2016.

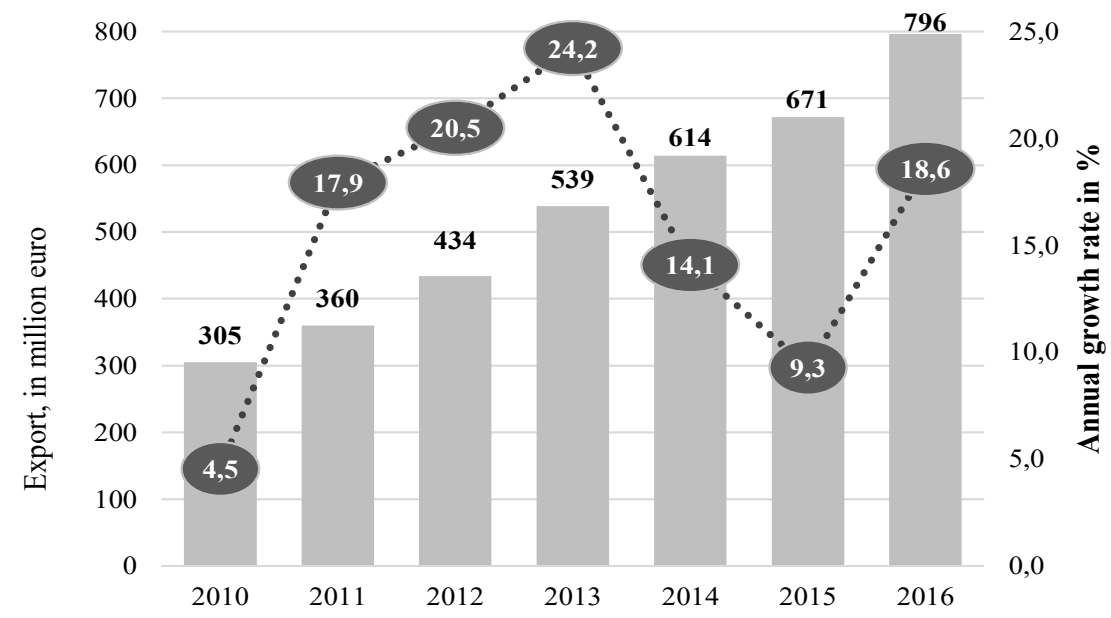

Source: authors, based on the Republic Statistical Office's data

\section{The perspective of development of textile industry in Serbia}

Global movements in the textile industry and business environment in Serbia are a major challenge for the development of the textile industry and the acceleration of exports of textiles and textile products. Although the textile industry in Serbia is not at the level it had three or more decades ago, positive trends have been evident in the last few years, whether it is the development of originally domestic companies or the arrival of foreign companies and the beginning of their production in Serbia.

The revival of the textile industry is of great economic and social significance, because it is an activity in which Serbia possesses basic comparative advantages (lower labour costs, long tradition of production, qualification and availability of workers, favorable geographical location) and labour intensive activity that engages a large number of predominantly women, less skilled workforce, which is attractive in an entrepreneurship way and export oriented and it is often located in less developed areas, which has a positive impact on more balanced economic development.

The significance of the revival and acceleration of the development of the textile industry has been recognised at the state level. In addition to activities aimed at maintaining a stable macroeconomic environment and improving general business conditions, the Government of the Republic of Serbia, through the 
Ministry of Economy and Associated Institutions (Development Agency of Serbia and the Development Fund), also undertook concrete activities to increase production in the manufacturing industry, especially to the development of the textile industry. The need for a state reaction has been largely exhausted because inefficient privatisation and over-exposure to global competition due to the rapid liberalisation of textile and textile imports have caused drastic deterioration of business and the extinguishing of once large and successful textile industrial systems and slow development of new domestic textile enterprises.

With the disappearance of formerly large domestic textile systems such as Jumko, Prvi maj, Nitex, Beko, Kluzo, etc., significant unpackaged capacities appeared within the textile industry that was to be activated, first of all through foreign and/or domestic direct investments, parallel to the development of small and medium enterprises entrepreneurially oriented. For this purpose, through the Investment Law and the Regulation on Attracting Direct Investment, incentive funds for attracting foreign and domestic investments in the textile industry have been found, regardless to textile production or clothing production.

In the period 2006-2018, incentives for the realisation of 44 projects within the textile industry (14 projects in the production of textiles and 30 in the production of clothing items) were approved from the budget of the Republic of Serbia. The realisation of these projects will invest more than 307 million euros $(14.9 \%$ of the value of all investment projects that have received incentive funds) and employ more than 16 thousand workers $(20.7 \%$ of all employees who will be employed through subsidised projects), whereby incentives were granted in the amount of about $€ 80$ million ( $15.5 \%$ of all approved incentives).

Most incentives within the textile industry were awarded to projects invested by foreign companies (mostly from Italy, Germany and Turkey). Foreign investors are implementing 33 projects, with the value of their investments $97.7 \%$ of the value of subsidised investments in the textile industry. The realisation of these 33 projects will enable the employment of about 15 thousand workers $(93.9 \%$ of workers who will be employed in the textile industry on the basis of subsidised funds), and foreign investors were granted incentive funds in the amount of 75 million euros, which is $94.5 \%$ of all funds approved for projects in the textile industry.

In this way, large globally known companies in the field of the textile industry such as Italian Benetton, Valy, Confezioni Andrea, Flash, Fiorano, as well as Gordon from Luxembourg and Eurotay from Turkey, have come in the textile industry of Serbia. Most of these investments are in the form of brownfield investments (eg Benetton bought former Nitex plants in Nis), but there are also examples of classic Greenfield investments like the investment of Turkish Eurotay in Kraljevo. 
Table 6. Subsidised direct investments in the textile industry in the period 2006-2018

\begin{tabular}{||c|c|c|r|r|r||}
\hline \multirow{4}{*}{$\begin{array}{l}\text { Manufacture of } \\
\text { textiles }\end{array}$} & $\begin{array}{c}\text { Origin of } \\
\text { investors }\end{array}$ & $\begin{array}{c}\text { Number of } \\
\text { projects }\end{array}$ & $\begin{array}{c}\text { Height of } \\
\text { investment } \\
\text { (in euros) }\end{array}$ & $\begin{array}{c}\text { New } \\
\text { workplaces }\end{array}$ & $\begin{array}{c}\text { Approved } \\
\text { incentives } \\
\text { (in euros) }\end{array}$ \\
\cline { 2 - 6 } & fomestic & 2 & 2.055 .000 & 112 & 448.000 \\
\cline { 2 - 6 } & foreign & 12 & 81.096 .376 & 4.185 & 20.038 .830 \\
\hline \multirow{3}{*}{$\begin{array}{l}\text { Manufacture of } \\
\text { clothes }\end{array}$} & total & $\mathbf{1 4}$ & $\mathbf{8 3 . 1 5 1 . 3 7 6}$ & $\mathbf{4 . 2 9 7}$ & $\mathbf{2 0 . 4 8 6 . 8 3 0}$ \\
\cline { 2 - 7 } & fomestic & 9 & 23.503 .587 & 857 & 3.899 .329 \\
\cline { 2 - 7 } Textile \\
industry & total & $\mathbf{3 0}$ & $\mathbf{2 2 3 . 7 0 5 . 4 0 8}$ & $\mathbf{1 1 . 4 6 5}$ & $\mathbf{5 9 . 0 5 4 . 8 5 3}$ \\
\hline \multirow{3}{*}{$\begin{array}{l}\text { Total allocated } \\
\text { incentive funds }\end{array}$} & domestic & $\mathbf{1 1}$ & $\mathbf{2 5 . 5 5 8 . 5 8 7}$ & $\mathbf{9 6 9}$ & $\mathbf{4 . 3 4 7 . 3 2 9}$ \\
\cline { 2 - 7 } & foreign & $\mathbf{3 3}$ & $\mathbf{2 8 1 . 2 9 8 . 1 9 7}$ & $\mathbf{1 4 . 7 9 3}$ & $\mathbf{7 5 . 1 9 4 . 3 5 4}$ \\
\cline { 2 - 7 } & total & $\mathbf{4 4}$ & $\mathbf{3 0 6 . 8 5 6 . 7 8 4}$ & $\mathbf{1 5 . 7 6 2}$ & $\mathbf{7 9 . 5 4 1 . 6 8 3}$ \\
\cline { 2 - 7 } & foreign & $\mathbf{1 7 3}$ & $\mathbf{1 . 9 0 4 . 6 0 8 . 7 3 9}$ & $\mathbf{7 0 . 4 0 2}$ & $\mathbf{4 8 6 . 3 4 2 . 9 3 7}$ \\
\cline { 2 - 7 } & total & $\mathbf{2 4 5}$ & $\mathbf{2 . 0 5 5 . 0 3 5 . 1 4 3}$ & $\mathbf{7 6 . 3 1 2}$ & $\mathbf{5 1 2 . 4 7 8 . 7 5 1}$ \\
\hline
\end{tabular}

Source: authors, based on data from the Ministry of Economy

However, apart from the positive effects of these foreign direct investments on employment growth and the revival and development of the textile industry in Serbia, the arrival of previously mentioned foreign investors shows significant weaknesses in the domestic textile industry and the economy as a whole. Actually, this is the main motive for the arrival of foreign investors. Most foreign investors chose Serbia as a place to invest due to significant financial subsidies (over 5,000 euros per employee), cheap labour (wages are generally significantly lower than average) and lower operating costs (for example, electricity costs, heating, utilities, etc.).

Bearing in mind that, in Serbia, production operations are generally carried out with lower added value, such as sewing and knitting, and that operations that generate greater added value in the production chain, such as designing, branding or promotion, are performed either in the home countries of the investor or in other countries where these investors also operate, we can come to the conclusion that the development of textile industry, which is primarily based on foreign direct investment, is a long-term unsustainable concept with very limited development opportunities.

The number of projects implemented and the value of incentives granted to domestic investors in the textile industry is significantly lower in relation to incentives granted to foreign investors. Only 11 agreements on the grant of incentive funds were signed with domestic investors, two contracts with textile manufacturers (Montegi doo Niš and Bim Tex doo Leskovac) and 9 contracts with producers of garments (Exkluziv doo Kuršumlija, Giovani Nord doo Jaša Tomić, 
Modital doo Zrenjanin, Ivković doo Grocka, Cameleon doo Svrljig, Capital Group doo Belgrade, Ivko Knits doo Boleč, Trendtex doo Brodarevo and Fush doo Belgrade). The total planned value of domestic investments is $€ 25.6$ million (only $8.3 \%$ of the value of subsidised investments in the textile industry), and it is planned to employ 969 workers $(6.1 \%$ of workers who will be employed in the textile industry on the basis of subsidized funds). For the realisation of these 11 domestic projects, the funds for incentives in the amount of 4.3 million euros (4.5 thousand euros per employee) were approved, which is only $5.5 \%$ of all incentive funds approved for projects in the textile industry. Unlike foreign investors who did not implement any project in devastated areas, even three domestic projects (Exkluziv doo Kuršumlija, Cameleon doo Svrljig and Trendtex doo Brodarevo) are implemented in devastated areas (Kuršumlija, Svrljig and Prijepolje), which reduces the expressed regional inequality in the development of municipalities in Serbia. Also, five domestic investment projects represent greenfield investments (Exklusive doo Kuršumlija, Giovani Nord doo Jaša Tomić, Modital doo Zrenjanin, Ivković doo Grocka, Montegi doo Niš, Bim Tex doo Leskovac, Cameleon doo Svrljig and Capital Group doo Belgrade). What is more, the amount of investment per employee is higher in domestic (26.376.25 euros per employee) than foreign investors (19.015.63 euros per employee), which indicates a higher technological intensity of domestic than foreign investments in the textile industry.

Starting from previous research, in order to make the revival and growth of the textile industry more dynamic and sustainable in the long term, it is necessary to encourage the development of those activities in the production chain that generate greater added value and reduce the impact of fragmentation on the competitiveness of domestic producers. In this direction, it is necessary to support existing and potentially new domestic producers, especially in the field of the fashion industry, because they are companies that have developed their own design and built a recognisable brand and are suitable for connecting with other companies that operate in the areas of creative industry and services. It is also necessary to stimulate the arrival of new foreign manufacturers in the form of FDI that are focused on activities that generate multiple levels of added value, such as design, branding or promotion. At the same time, it is necessary to encourage and support the integration and association of textile enterprises into clusters, strategic alliances, technology parks, and thus facilitate access to capital, knowledge and technologies, information, markets, and enhance brand building and promotion at domestic and foreign markets. The future of the domestic textile industry is not in the qualitative increase in capacities and the production of products of low added value, but in qualitative development based on the application of modern technological solutions, the latest fashion trends and the production of high added value products. 


\section{References}

EURACTIVE (2018). European Textiles and Fashion: Facts \& Figures, [online] Available at: http://www.euractiv.com/section/innovation-industry/infographic/europeantextiles-and-fashion-facts-figures/ (Accessed 1 Sep. 2018).

Group of authors (2003). Competitiveness of the Serbian economy, Belgrade: Jefferson Institute.

Irun, B. (2017). Business Opportunities and Challenges in the Textile and Apparel Market in China, EU SME Centre, Beijing, China

Kathuria, S., Martin, W. \& Bhardwaj, A. (2001). Implications for South Asian Countries of Abolishing the Multifibre Arrangement, Policy Research Working Paper No. 2721, Washington: The World Bank.

OECD (2004). A New World Map in Textiles and Clothing: Adjusting to Change, Paris: Organisation for Economic Cooperation and Development.

Statistical Office of the Republic of Serbia, (2018). Annual business indicators of the company, Available at: http://data.stat.gov.rs/Home/Result/190101?languageCode $=$ sr-Cyrl (Accessed 28 June 2018).

Ministry of Economy (2018). (online) Available at: http://privreda.gov.rs/ministarstvo-nadlanu/sektori/odeljenje-za-investicije/ (Accessed 24 June 2018).

\section{RAZVOJNE PERFORMANSE TEKSTILNE INDUSTRIJE SRBIJE}

Rezime: Tekstilna industrija još uvek značajno učestvuje u proizvodnji i zaposlenosti u razvijenim zemljama i značajan je izvor rasta u mnogim zemljama u razvoju. Kao delatnost sa dugom istorijom, tekstilna industrija prolazi kroz radikalne transformacije na globalnom nivou. Pojavom novih konkurenata uslovi poslovanja na globalnom nivou su značajno promenjeni. Uprkos tome, evropski proizvođači su ostali svetski lideri u proizvodnji industrijskog tekstila i modne odeće. Da bi održali konkurentnost, mnogi evropski proizvođači pribegavaju podugovaranju ili premeštaju kapaciteta za radno intenzivne aktivnosti u zemljama sa nižim troškovima rada poput Srbije. Najveći uspeh domaća tekstilna industrija beležila je krajem 1980-ih godina prošlog veka kada je bila značajan izvor zapošljavanja, stvaranja dodate vrednosti i ravnomernijeg regionalnog razvoja. U 2016. godini, iako još uvek nije na nivou iz 1980-ih, prisutna su pozitivna kretanja u domaćoj tekstilnoj industriji u pravcu rasta proizvodnje, zaposlenosti i izvoza. Država nastoji da kroz subvencionisanje stranih i domaćih investitora ubrza razvoj tekstilne industrije. Međutim, rast koji se prevashodno zasniva na stranim direktnim investicijama dugoročno je neodrživ koncept. Da bi rast bio održiv, potrebno je da se podstiče razvoj aktivnosti koje stvaraju veću dodatu vrednost i povećaju konkurentnost. Zato je potrebno podržati razvoj domaćih preduzeća, kao i dolazak onih stranih investicija koje generišu više nivoe dodate vrednosti.

Ključne reči: tekstilna industrija, poslovne performanse, domaće i strane investicije, razvoj 


\section{Authors' biographies}

Vladimir Kostić was born in 1985 . He received his $\mathrm{PhD}$ at the Faculty of Economics in Nis. He is an assistant professor at the Faculty of Economics in Kosovska Mitrovica, University of Pristina. He is particularly interested in the themes of theory and economic development policy, as well as the problems of the contemporary economic crisis. $\mathrm{He}$ is a participant in international conferences at home and abroad. He has published a number of papers in domestic and foreign journals.

Miloš Milutinović was born in 1979 in Niš. He completed his basic studies in the field of management at the BK (Alfa) University in Belgrade, and in 2018, he defended the master thesis titled "Crisis Management and Organization Transformation" at the Faculty of Applied Management, Economics and Finance (MEF) from Belgrade, University Business Academy in Novi Sad. He is a director of the Belgrade Educational Center, an advisor in Business development solution and a consultant in the field of management, reorganization and restructuring of companies from different branches in Serbia, Croatia and Bosnia and Herzegovina. He has developed feasibility studies, justification of investment projects, market analysis, diligence, business plans and strategies, marketing strategies, sales plans, etc. for more than 30 companies. He is the author of a number of works published in domestic and foreign journals in the field of management and economics.

Miroljub Nikolić graduated (2004) and received M.A. (2009) at the Faculty of Economics in Belgrade, and acquired $\mathrm{PhD}$ title at the Faculty of Economics in Niš (2014). He is currently employed at the Ministry of Economy. He is author of several scientific papers in the field of economic and innovation development, entrepreneurship, small and medium-sized enterprises. He participated in the preparation of a large number of different national research projects and studies, particularly in the field of economic and regional development (National Strategy for Economic Development of Serbia 2006-2012, Industrial Policy of Serbia 2011-2020, National Plan of Regional Development of the Republic of Serbia 2014-2020), economic restructuring (Industrial Policy of Serbia 2011-2020, Public Companies' Operations Report, 100 Most Successful Companies in Serbia), entrepreneurship and small and medium-sized enterprises, etc. He is a member of Scientific Society of Economists, and the Presidency of the Belgrade Association of Economists. 